\title{
Low back pain and coping strategies' among nurses in Port Said City, Egypt
}

\author{
Maha Moussa Mohamed Moussa , Hanan Hassan El-Ezaby, Reda Ibrahim El-Mowafy \\ Department of Community Health Nursing, Faculty of Nursing, Port Said University, Port Said, Egypt
}

Received: January 24, 2015

Accepted: March 30, 2015

Online Published: April 27, 2015

DOI: $10.5430 /$ jnep.v5n7p55

URL: http://dx.doi.org/10.5430/jnep.v5n7p55

\begin{abstract}
Background: Low back pain is a very common health problem worldwide and a major cause of disability-affecting performance at work and general well-being. The aim of this study was to assess low back pain and coping strategies' among nurses in Port Said City.

Methods: This was a cross-sectional study of low back pain among 419 nurses working in six governmental hospitals and four primary health care centers in Port-Said City. Data were collected through face-to-face interviews using five tools.

Results: A total of 419 completed questionnaires were analyzed. The mean pain severity score was $5.8 \pm 1.8$. The present study revealed that a highly statistically significant relation between pain score, perception, and coping strategies and age, body mass index, experience, and duration of low back pain among nurses complaints of low back pain.

Conclusions: More than three quarters of nurses suffered from low back pain due to long standing and more than two thirds due to heavy lifting and hospital work. With respect to strategies for coping with low back pain, positive correlations were found between withdrawal and denial as a coping strategy with age and experience.
\end{abstract}

Key Words: Low back pain, Coping strategies, Nurse

\section{INTRODUCTION}

Low back pain predominantly affects the working population in both developed and developing nations, leaving a number of individuals disabled. ${ }^{[1-3]}$ Chronic low back pain may originate from an injury, disease, or stresses on different structures of the body. The type of pain may vary greatly and may be felt as bone pain, nerve pain or muscle pain. The sensation of pain may also vary. For instance, pain may be achy, burning, stabbing or tingling, sharp or dull, and well-defined or vague. The intensity may range from mild to severe. Nursing is well established as a high-risk occupation for musculoskeletal disorders and, in particular, low back pain (LBP). ${ }^{[4,5]}$ Prevalence increases and peaks between the ages of 35 and 55. As the world population ages, low back pain will increase substantially due to the deterioration of the intervertebral discs in older people, it is estimated that 3.5\% of nurses are leaving the profession due to back pain. ${ }^{[6,7]}$

Although several risk factors have been identified, including occupational posture, depressive moods, obesity, body height, and age, the causes of the onset of low back pain remain obscure and the diagnosis is difficult to make. ${ }^{[8-10]}$ Most physical risks contributing to LBP in nurses are focused on occupational factors such as extent of bending and lifting. ${ }^{[1]}$ A range of personal physical factors, including reduced cardiovascular fitness, ${ }^{[12]}$ poor back muscle endurance, ${ }^{[13]}$ altered motor control patterns, ${ }^{[14]}$ poor spinal posture, ${ }^{[15]}$ and

\footnotetext{
*Correspondence: Maha Moussa Mohamed Moussa; Email: mahamoussa10@yahoo.com; Address: Department of Community Health Nursing, Faculty of Nursing, Port Said University, Port Said, Egypt.
} 
reduced sagittal range of motion ${ }^{[16,17]}$ have been found in various LBP populations. Further, lifestyle factors such as physical inactivity ${ }^{[18]}$ and high levels of vigorous physical activity $^{[19]}$ have been associated with LBP.

Recently, there has been an increased focus on factors that may be associated with the prognosis of musculoskeletal pain, with particular interest in the significance of coping strategies and the scope for modification to improve outcomes. ${ }^{[20]}$ Coping, as defined by Hestbaek, Leboeuf, and Kyvik $^{[21]}$ is a process of evaluating a stressful situation consisting of primary and secondary appraisal and responding to a stressor. Coping with medical conditions may also be influenced by the illness perceptions of an individual and emotional response to the perceived health threat. ${ }^{[22]}$ The coping strategies people use may have potential to affect the outcome of their condition. There is an abundance of cross-sectional studies, ${ }^{[23,24]}$ demonstrating an association between coping strategies and pain and disability, particularly for patients with low back pain.

\section{SUBJECT AND METHODS}

\subsection{Research design}

A cross-sectional study design was used to assess low back pain and coping strategies' among nurses in Port Said City.

\subsection{Setting}

This study was carried out in six governmental hospitals(ELNaser Hospital ,EL-Mobara Hospital, EL-Amiri Hospital, EL-Tadamon Hospital, EL-Zhour Hospital and Port-fouad General Hospital ) and four primary health care centers (Othman Bin Afan, Omer Bin El-khatab, EL-Kuwait and ELMonakh) in Port Said City.

\subsection{Target population}

The Target population for this study was female nurses working in the governmental hospitals and primary health care centers mentioned above.

\subsection{Subjects}

All nurses (419) available in the above mentioned settings at the time of data collection were included in this study.

Exclusion criteria: Subjects were excluded as: inflammatory disorders, neurological diseases, metastatic disease, spinal surgery and pregnancy.

\subsection{Tools for data collection}

Data were collected using five tools.

Tool (I): A structured interview questionnaire addressed socio-demographic data related to the nurse's age, nursing educational levels, experience (years), marital status, workplace, duration of LBP, LBP related to position and alleviating factors.

Tool (II): A linear numerical scale developed by Boyd, $2003^{[25]}$ uses a 10-point numerical scale describing the degree of pain experienced with zero indicating no pain at all and 10 representing the worst degree of pain.

Tool (III): Perceived Meaning of Pain Inventory (PMPI): The PMPI is a norm-referenced measure designed to determine the meaning of pain as described by patients. ${ }^{[26]}$ It consists of 26 items comprising 5 scales: loss (5-items), threat (9-items), blaming others (4-items), blaming self (4-items), and spiritual awareness (4-items). Each item is followed by a 3-point scale for measuring the degree to which an items represents the subjects thoughts about pain. The Perceived Meaning of pain(26 point) ranged from 1 to 3 where $1=$ never thinking, $2=$ most of time thinking and $3=$ all time thinking.

Tool (IV): The ways of coping questionnaire(WCQ): This scale was developed by Folkman and Lazarus (1988). ${ }^{\text {[27-29] }}$ It was used to measure cognitive and behavioral effort. The scale consists of 33 items divided into three subscales: positive coping (15 items), avoidant coping (10 items), and alleviating coping (8items) to indicate on a (4 point likert scale) ranging from 0 to 3 , where $0=$ not used, $1=$ used somewhat, 2 = used quite a bit and $3=$ used a great deal what the enough, cope with the demands of pain. The standardized Alfa coefficient for the 35 items WCQ was 0.94 by Folkman and Lazarus (1988). The standardized coefficient for factors ranged from 0.76 to 0.84 .

Tool (V): State-Trait Anxiety Inventory (STAI): This scale was developed by Spilberger et al. and Spilberger. ${ }^{[30,31]}$ It was used to measure distinct trait anxiety among patients with low back pain. A-State scale consists of 20 statements, asked the patients to describe how they generally feel. Subject responded on each STAI items by rating on a point scale ranging from 1 (low anxiety) to 4 (high anxiety). Alfa reliability for A-State ranged from 0.86 to 0.92 subjects respond to each STAI items by rating on a 4-point scale ranging from no anxiety (zero) to high anxiety (3-points). The 4 categories for the scoring system are $0=$ not at all, $1=$ somewhat $2=$ moderately so and $3=$ very much so.

\subsection{Validity}

The study tools were tested for validity by five experts; two from the Medical Surgical Nursing and three Community Health Nursing Departments of Port Said University. 


\subsection{Pilot study}

A pilot study was carried out on $10 \%$ of the study sample to test the tools for clarity, applicability, and the time required to complete the tools. Data obtained from the pilot study were analyzed and feedback was requested concerning the wording of questions, how long it took to complete and whether any of the questions were felt to be overly intrusive. Feedback was very positive and as a result the questionnaire remained unchanged. Those who participated in the pilot study were excluded from the main study sample.

\subsection{Fieldwork}

Questionnaires were completed by the nurses. Data were collected from the selected settings by the researchers from the beginning of January to the end of June 2013. The research team members were present during completion of the questionnaires, and completion took 30-45 minutes for each participant.

\subsection{Ethical considerations}

Approval to conduct the study was obtained from the Dean of Faculty of Nursing at Port Said University and from each of the hospitals and primary health care centers. Each nurse received an explanation of the purpose of the study and how to complete the study tools. They were assured of the confidentiality of all data they provided and the use of data for research purposes only.

\subsection{Statistical design}

The Statistical Package for the Social Sciences (SPSS, version 16.0) was used for data analysis. Descriptive statistics were employed to summarize the demographic data, which was presented using frequency tables and expressed as percentages, means, and standard deviations. The chi-square and Fisher exact test were used to determine if any associations existed between low back pain and socio-demographic variables.

Spearman rank correlation test was used to examine (Correlation between nurses' pain, perception, coping and anxiety scores and the personal characteristics). Statistically significance was considered at $p$-value $<.05$.

\section{RESUlTS}

Characteristics of low back pain (LBP) are depicted in Table 1, duration of LBP ranged from less than 2 years to more than 10years. The majority $(90 \%)$ of the nurse shad LBP related to position, with more than three quarters $(75.6 \%)$ attributing their low back pain to long standing. In addition, and more than two-thirds (of the nurses were suffering from low back pain due heavy lifting and hospital work $(67.5 \%$ $\& 66.5 \%$ ) respectively. Bending reported by $58.9 \%$ of the nurses. Meanwhile pain alleviated by rest and sitting, standing after a long period and ling down as reported $(68 \%$ \& $40.3 \%$ ) respectively. The mean pain severity score among the nurses was $5.8(+1.8)$ out of 10. Regarding strategies to alleviate low back pain, $(68 \%)$ of the study sample used rest and sitting. Other strategies included standing after a long period lying down $(40.3 \%)$ or sitting $(26.7 \%)$, sitting after walking $(25.7 \%)$.

Table 1. Characteristics of low back pain (LBP) among nurses in the study sample $(n=419)$

\begin{tabular}{lll}
\hline & Frequency & Percent \\
\hline Duration of LBP (years): & & \\
$<2$ & 62 & $15.6 \%$ \\
$2-4$ & 170 & $42.8 \%$ \\
$5-9$ & 96 & $24.2 \%$ \\
$10+$ & 69 & $17.4 \%$ \\
LBP related to causes & 358 & $90.2 \%$ \\
Types of causes: & & \\
Long sitting & 157 & $39.5 \%$ \\
Long standing & 300 & $75.6 \%$ \\
During long walking & 183 & $46.1 \%$ \\
Sudden movement & 171 & $43.1 \%$ \\
Heavy lifting things & 268 & $67.5 \%$ \\
Bending & 234 & $58.9 \%$ \\
Home chores & 242 & $61.0 \%$ \\
Hospital work & 264 & $66.5 \%$ \\
Waking up & 118 & $29.7 \%$ \\
Alleviated by: & & \\
Standing after a long period sitting & 106 & $26.7 \%$ \\
Standing after a long period lying down & 160 & $40.3 \%$ \\
After walking & 102 & $25.7 \%$ \\
Rest and sitting & 270 & $68.0 \%$ \\
Pain severity score (max=10): & & \\
Range & $2.5-10.0$ & \\
Mean \pm SD & $5.8 \pm 1.8$ & \\
Median & 5.00 & \\
\hline & & \\
\hline
\end{tabular}

Table 2 indicates that a highly statistically significant relation was found between low back pain and age in the study sample ( $p$-value .04). Low back pain was also significantly related to study sample having children $(p=.03)$ and gravidity (.001).

Table 3 shows that a highly statistically significant relation between pain due to low back pain among the study sample with duration of LBP, nursing work affected, treatment used and used special therapies $(p$-value $<.001, .008, .003, .03 \&$ .002) respectively.

Table 4 indicates a highly statistically significant relation between low back pain and feelings of loss, feelings of thereat and anxiety $(p<.001, .03, \& .001)$ respectively. 
Table 2. Relation between low back pain (LBP) among nurses and their personal and health characteristics

\begin{tabular}{|c|c|c|c|c|c|c|}
\hline & \multicolumn{4}{|c|}{ LBP } & \multirow{3}{*}{$\chi^{2}$ Test } & \multirow{3}{*}{$p$-value } \\
\hline & \multicolumn{2}{|c|}{ Absent } & \multicolumn{2}{|c|}{ Present } & & \\
\hline & No. & $\%$ & No. & $\%$ & & \\
\hline \multicolumn{7}{|l|}{ Age (years): } \\
\hline$<30$ & 15 & 68.2 & 176 & 44.3 & \multirow{3}{*}{6.63} & \multirow{3}{*}{$.04 *$} \\
\hline $30-$ & 6 & 27.3 & 115 & 29.0 & & \\
\hline $40+$ & 1 & 4.5 & 106 & 26.7 & & \\
\hline \multicolumn{7}{|l|}{ Body mass index (BMI): } \\
\hline Normal $(<25)$ & 9 & 40.9 & 109 & 27.5 & \multirow{3}{*}{1.88} & \multirow{3}{*}{.39} \\
\hline Overweight $(25-<30)$ & 7 & 31.8 & 150 & 37.8 & & \\
\hline Obese $(30+)$ & 6 & 27.3 & 138 & 34.8 & & \\
\hline \multicolumn{7}{|l|}{ Educational degree: } \\
\hline Nursing school diploma & 18 & 81.8 & 354 & 89.2 & \multirow{2}{*}{ Fisher } & \multirow[t]{2}{*}{.29} \\
\hline Bachelor’s degree & 4 & 18.2 & 43 & 10.8 & & \\
\hline \multicolumn{7}{|l|}{ Experience: } \\
\hline$<5$ & 5 & 22.7 & 71 & 17.9 & \multirow{3}{*}{5.11} & \multirow{3}{*}{.08} \\
\hline 5- & 9 & 40.9 & 90 & 22.7 & & \\
\hline $10^{+}$ & 8 & 36.4 & 236 & 59.4 & & \\
\hline \multicolumn{7}{|l|}{ Current marital status: } \\
\hline Married & 9 & 40.9 & 112 & 28.2 & \multirow{2}{*}{1.84} & \multirow{2}{*}{.20} \\
\hline Unmarried & 13 & 59.1 & 285 & 71.8 & & \\
\hline \multicolumn{7}{|l|}{ Have children: } \\
\hline No & 4 & 30.8 & 29 & 9.4 & \multirow{2}{*}{ Fisher } & \multirow[t]{2}{*}{$.03 *$} \\
\hline Yes & 9 & 69.2 & 278 & 90.6 & & \\
\hline \multicolumn{7}{|l|}{ Gravidity: } \\
\hline 0 & 4 & 30.8 & 23 & 7.5 & \multirow{3}{*}{13.36} & \multirow{3}{*}{$.001^{*}$} \\
\hline 1 & 4 & 30.8 & 41 & 13.4 & & \\
\hline $2+$ & 5 & 38.5 & 243 & 79.2 & & \\
\hline \multicolumn{7}{|l|}{ History of abortion: } \\
\hline No & 5 & 55.6 & 203 & 71.5 & \multirow{2}{*}{ Fisher } & \multirow[t]{2}{*}{.29} \\
\hline Yes & 4 & 44.4 & 81 & 28.5 & & \\
\hline
\end{tabular}

Table 3. Relation between pain due to low back pain (LBP) among nurses and their illness characteristics

\begin{tabular}{|c|c|c|c|c|c|}
\hline & \multicolumn{3}{|c|}{ Pain score $(\max =10)$} & \multicolumn{2}{|l|}{ Kruskal } \\
\hline & Mean & SD & Median & Wallis Test & $p$-value \\
\hline \multicolumn{6}{|c|}{ Duration of LBP (years) } \\
\hline$<2$ & 5.16 & 1.62 & 5.00 & \multirow{4}{*}{19.33} & \multirow{4}{*}{$<.001 *$} \\
\hline $2-4$ & 5.68 & 1.86 & 5.00 & & \\
\hline $5-9$ & 6.25 & 1.66 & 5.00 & & \\
\hline $10+$ & 6.27 & 1.99 & 7.50 & & \\
\hline \multicolumn{6}{|c|}{ LBP related to position } \\
\hline No & 5.51 & 1.74 & 5.00 & \multirow[t]{2}{*}{1.02} & \multirow[t]{2}{*}{.31} \\
\hline Yes & 5.87 & 1.85 & 5.00 & & \\
\hline \multicolumn{6}{|l|}{ Aggravating factors } \\
\hline No & 6.08 & 1.97 & 7.50 & \multirow[t]{2}{*}{1.28} & \multirow[t]{2}{*}{.26} \\
\hline Yes & 5.81 & 1.82 & 7.50 & & \\
\hline \multicolumn{6}{|l|}{ Alleviating factors } \\
\hline No & 5.76 & 3.38 & 5.00 & \multirow[t]{2}{*}{1.06} & \multirow[t]{2}{*}{.30} \\
\hline Yes & 5.93 & 3.39 & 5.00 & & \\
\hline \multicolumn{6}{|c|}{ LBP affects work relations } \\
\hline No & 5.65 & 1.86 & 5.00 & \multirow[t]{2}{*}{6.94} & \multirow[t]{2}{*}{$.008^{*}$} \\
\hline Yes & 6.15 & 1.78 & 5.00 & & \\
\hline \multicolumn{6}{|c|}{ LBP affects nursing work } \\
\hline No & 5.60 & 1.92 & 5.00 & \multirow[t]{2}{*}{8.82} & \multirow[t]{2}{*}{$.003^{*}$} \\
\hline Yes & 6.14 & 1.69 & 5.00 & & \\
\hline \multicolumn{6}{|l|}{ Treatment used } \\
\hline No & 5.40 & 2.07 & 5.00 & \multirow[t]{2}{*}{4.83} & \multirow[t]{2}{*}{$.03 *$} \\
\hline Yes & 5.92 & 1.79 & 5.00 & & \\
\hline \multicolumn{6}{|c|}{ Type of treatments used } \\
\hline Analgesics & 6.14 & 1.73 & 5.00 & \multirow{3}{*}{5.24} & \multirow{3}{*}{.07} \\
\hline Rest & 5.70 & 1.72 & 5.00 & & \\
\hline Medications & 6.25 & 2.73 & 6.25 & & \\
\hline \multicolumn{6}{|c|}{ Used special therapies } \\
\hline No & 5.48 & 1.81 & 5.00 & \multirow[t]{2}{*}{9.61} & $.002 *$ \\
\hline Yes & 6.09 & 1.82 & 5.00 & & \\
\hline Types of therapies & & & & & \\
\hline Physiotherapy & 6.12 & 1.72 & 5.00 & & \\
\hline Physical exercise & 5.36 & 2.13 & 5.00 & 3.02 & .22 \\
\hline Weight loss & 6.11 & 1.54 & 6.25 & & \\
\hline
\end{tabular}

$\left({ }^{*}\right)$ Statistically significant at $p<.05$. 
Table 4. Relation between pain due to low back pain (LBP) among nurses and their perception of pain and anxiety

\begin{tabular}{|c|c|c|c|c|c|}
\hline & \multicolumn{3}{|c|}{ Pain score $(\max =10)$} & \multirow{2}{*}{ Kruskal Wallis Test } & \multirow{2}{*}{$p$-value } \\
\hline & Mean & SD & Median & & \\
\hline \multicolumn{6}{|c|}{ Feelings of loss: } \\
\hline High & 6.68 & 1.73 & 7.50 & 21.86 & $<.001^{*}$ \\
\hline Low & 5.60 & 1.80 & 5.00 & & \\
\hline \multicolumn{6}{|c|}{ Feelings of threats: } \\
\hline High & 6.81 & 1.67 & 7.50 & 4.79 & $.03 *$ \\
\hline Low & 5.79 & 1.84 & 5.00 & & \\
\hline \multicolumn{6}{|c|}{ Feelings of blaming others: } \\
\hline High & 6.02 & 1.84 & 5.00 & 0.25 & .62 \\
\hline Low & 5.83 & 1.84 & 5.00 & & \\
\hline \multicolumn{6}{|c|}{ Feelings of self-blame: } \\
\hline High & 5.89 & 1.52 & 5.00 & 0.01 & .91 \\
\hline Low & 5.83 & 1.88 & 5.00 & & \\
\hline \multicolumn{6}{|c|}{ Spiritual feelings: } \\
\hline High & 6.32 & 1.87 & 6.25 & 2.22 & .14 \\
\hline Low & 5.79 & 1.83 & 5.00 & & \\
\hline \multicolumn{6}{|c|}{ Total perception: } \\
\hline High & 6.04 & 1.73 & 5.00 & 0.12 & .73 \\
\hline Low & 5.82 & 1.85 & 5.00 & & \\
\hline \multicolumn{6}{|c|}{ Anxiety: } \\
\hline High & 6.63 & 1.77 & 7.50 & 12.12 & $<.001^{*}$ \\
\hline Low & 5.70 & 1.82 & 5.00 & & \\
\hline
\end{tabular}

$\left({ }^{*}\right)$ Statistically significant at $p<.05$.

As indicated in Table 5, no statistically significant relationships were found between pain and use of any types of coping measured.

Table 6 indicates positive correlation between pain score with age, BMI, experience, number of children, gravidity, number of abortion and duration of low back pain among nurses.
While negative correlation pain score with educational degree. Concerning coping strategies, it was found a positive correlation between use of effective coping mechanism with age, number of children, gravidity, and a positive correlation between coping by withdrawal with age and experience. Also it was noticed that a positive correlation between coping by denial with age and experience.

Table 5. Relation between pain due to low back pain (LBP) among nurses and their coping

\begin{tabular}{|c|c|c|c|c|c|}
\hline & \multicolumn{3}{|c|}{ Pain score $(\max =10)$} & \multirow{2}{*}{ Kruskal Wallis Test } & \multirow{2}{*}{$p$-value } \\
\hline & Mean & SD & Median & & \\
\hline \multicolumn{6}{|c|}{ Use of effective coping mechanism: } \\
\hline High & 6.12 & 1.80 & 5.00 & \multirow[t]{2}{*}{1.74} & \multirow[t]{2}{*}{.19} \\
\hline Low & 5.77 & 1.85 & 5.00 & & \\
\hline \multicolumn{6}{|c|}{ Use of avoidant coping: } \\
\hline High & 6.32 & 1.41 & 6.25 & \multirow[t]{2}{*}{2.61} & \multirow[t]{2}{*}{.11} \\
\hline Low & 5.79 & 1.87 & 5.00 & & \\
\hline \multicolumn{6}{|c|}{ Use of alleviating(less intense) coping: } \\
\hline High & 5.93 & 2.00 & 5.00 & \multirow[t]{2}{*}{0.19} & \multirow[t]{2}{*}{67} \\
\hline Low & 5.82 & 1.82 & 5.00 & & \\
\hline \multicolumn{6}{|c|}{ Predominant coping used: } \\
\hline None & 5.77 & 1.84 & 5.00 & \multirow{4}{*}{1.36} & \multirow{4}{*}{.72} \\
\hline Positive & 6.01 & 1.81 & 5.00 & & \\
\hline Avoidant & 5.78 & 1.69 & 5.00 & & \\
\hline Alleviating & 5.74 & 1.97 & 5.00 & & \\
\hline
\end{tabular}

$(*)$ Statistically significant at $p<.05$. 
Table 6. Correlation between nurses' pain, perception, coping and anxiety scores and their personal characteristics

\begin{tabular}{|c|c|c|c|c|c|c|c|c|}
\hline & \multicolumn{8}{|c|}{ Spearman's rank correlation coefficient } \\
\hline & Age & BMI & $\begin{array}{l}\text { Educational } \\
\text { degree }\end{array}$ & Experience & $\begin{array}{l}\text { No. of } \\
\text { Children }\end{array}$ & Gravidity & $\begin{array}{l}\text { No. of } \\
\text { Abortions }\end{array}$ & $\begin{array}{l}\text { LBP } \\
\text { Duration }\end{array}$ \\
\hline Pain score & $.227 * *$ & $.145^{* *}$ & -0.09 & $.237 * *$ & $.192^{* *}$ & $.205^{* *}$ & 0.10 & $.177^{* *}$ \\
\hline \multicolumn{9}{|l|}{ Perception: } \\
\hline Loss & 0.08 & 0.06 & 0.00 & 0.09 & $.112 *$ & $.121^{*}$ & 0.07 & 0.07 \\
\hline Risk & $.124 *$ & $.173^{* *}$ & -0.07 & $.114^{*}$ & 0.06 & 0.06 & 0.04 & 0.03 \\
\hline Blame others & -0.02 & 0.01 & -0.05 & -0.04 & -0.06 & -0.06 & -0.05 & -0.07 \\
\hline Self-blame & 0.09 & 0.08 & $-.165^{* *}$ & 0.08 & 0.01 & 0.00 & 0.04 & -0.01 \\
\hline Spiritual & $.126 * *$ & $.131^{* *}$ & $-.130 * *$ & $.137^{* *}$ & $.123^{*}$ & 0.09 & 0.00 & 0.08 \\
\hline \multicolumn{9}{|l|}{ Coping: } \\
\hline Use of effective coping mechanism & $.117^{*}$ & 0.06 & -0.04 & 0.08 & $.157 * *$ & $.123^{*}$ & 0.04 & 0.07 \\
\hline Withdrawal & $.152^{* *}$ & 0.06 & -0.09 & $.147^{* *}$ & 0.09 & 0.04 & 0.01 & -0.01 \\
\hline Denial & $.188^{* *}$ & 0.10 & $-.105 *$ & $.174^{* *}$ & 0.04 & 0.04 & 0.04 & 0.06 \\
\hline Anxiety & -0.03 & $.110^{*}$ & -0.01 & 0.00 & 0.00 & 0.00 & -0.03 & -0.05 \\
\hline
\end{tabular}

$(*)$ Statistically significant at $p<.05 ;(* *)$ Statistically significant at $p<.01$.

\section{Discussion}

Nursing is a high-risk profession for the development of low back pain. In this study, low back pain was closely related to age ( $p$ value .04). These results are similar to the findings of the study among hospital employees at Tshwane Hospital in South Africa reported a higher prevalence of low back pain in those aged 26 to 40 years, as compared to other age groups. ${ }^{[32]}$ This is in agreement with data from the National Institute of Arthritis and Musculoskeletal and Skin Diseases ${ }^{[33]}$ report indicating that the first episode of LBP can be expected between the ages of 30 and 40 years.

Other socio-demographic characteristics of nurses in the present study revealed that increased severity of low back pain in married nurse. As regards education degree, the results of the present study have shown a higher workload and higher prevalence of LBP in nurses with hospital diplomalevel education compared to those with the higher their educational status as perhaps they delegate more physical care to others. Similarly, Balague et al. ${ }^{[34]}$ reported higher workloads and higher prevalence of LBP in nursing aides compared with licensed nurses.

According to the present study findings, cthere are many causes affecting condition of the nurse, the physical attributes of the work environment and patient care. The present study revealed that causes of LBP, such as standing for long periods of time, sitting posture or continuous sitting for more than one hour increasing intradiscal pressure, heavy lifting things. These findings are in accordance with many studies (National Institute of Arthritis and Musculoskeletal and Skin Diseases. Schlossmacher and Amaral, 2012, Warnakulasuriya et al., 2012, Karahan et al., 2009) ${ }^{[20,33,35,36]}$ who have agreed that activities such as lifting heavy patients, repetitive lifting and lifting alone contribute to LBP. The reasons why nurses tend to injure their backs during transfers include loss of balance (nurse and/or patient), failure to use a transfer device, sudden movement, and a poor physical work environment. In addition, lack of exercise is an important associated risk factor of LBP among nurses. Lack of exercise produces inadequate flexibility and weak muscles in the back, pelvis, and thighs, causing an increase of LBP.

The present study revealed that a positive correlation between age, BMI, experience, number of children, gravidity, number of abortion and duration of low back pain among nurses with score pain. These factors were found to have statistically significant relationships with LBP in our study. These results are in agreements with the findings of Heutink et al. ${ }^{[20,32,33,37]}$ who noted a similar association between age, obesity, experience and low back pain. Furthermore, Schlossmacher and Amaral ${ }^{[35]}$ reported that low back pain was 2.39 more common in obese individuals when compared with the respondents of normal weight and underweight. The findings of the present study revealed that a statically significance between LBP affects nursing work and pain score. These results are congruent with Schlossmacher et al. ${ }^{[20,32,35,38-40]}$ who indicated that more than two-thirds the nurses injuries were associated with the work load, work pressure and a poor environment at work were chosen by participants as being the most relevant factors that contribute to LBP.

Concerning coping strategies the present study revealed that positive correlation between pain perception and age, number of children and gravidity of the study sample these in the same line with Büssing \& Büssing ${ }^{[41,42]}$ who reported that most patients with chronic diseases use adaptive coping strategies which can be differentiated according to the uti- 
lization of external resources of health control. Furthermore, Ramirez-Maestr et al. \& Brown $1987^{[43,44]}$ reported that active coping(problem solving, including collecting information and refocusing on the problem, or regulation of emotion by focusing attention on the emotional response aroused by the stressor) is associated with less pain, less depression, less functional impairment, and higher general self-efficacy.

Regarding the correlation between pain perception and anxiety, the present study revealed that anxiety as a clinical stat had a significant correlation with pain perception. This is correlated with reports by Brown ${ }^{[44]}$ reveals that one of the most frequently used concept on adaptation strategies of patients with chronic pain diseases differentiates active and passive coping, while passive coping (avoidance and escape is correlated with reports of greater depression, greater pain and flare-up activity, greater functional impairment, and lower general self-efficacy.

Further studies are required, particularly longitudinal studies to measure changes in the weighting of adaptive coping strategies and interpretations of disease with respect to pain intensity, and comprehensive intervention programs.

\section{Conclusion}

Low back pain is common among nurses in Port-Said. More than three quarters of nurses were suffering from low back pain due to long standing and more than two third of nurses were suffering from low back pain due to heavy lifting and hospital work. With respect to strategies for coping with low back pain, positive correlations were found between withdrawal and denial as a coping strategy with age and experience.

\section{ACKNOWLEDGEMENTS}

The authors would like to express my deepest appreciation and sincere gratitude to everyone who has contributed to this work. In particular The authors would like to thank all the nurses guidance and constant support throughout this study. Without you, this study would not have been accomplished.

\section{CONFLICTS OF INTEREST Disclosure}

The authors report no conflicts of interest. The authors alone are responsible for the content and writing of the paper.

\section{REFERENCES}

[1] World Health Organization. International Classification of Functioning, Disability and Health (ICF) 2010. Available from: http: //www.who.int/classifications/icf/en

[2] Freburger JK, Holmes GM, Agans RP, et al. The rising prevalence of chronic low back pain. Arch Intern Med. 2009; 169(3): 251258. PMid:19204216 http://dx.doi.org/10.1001/archinter nmed.2008.543

[3] Roffey DM, Wai EK, Bishop P, et al. Causal assessment of occupational sitting and low back pain: results of a systematic review. Spine J. 2010; 10(3): 252-61. PMid:20097618 http://dx.doi.org/10. 1016/j.spinee.2009.12.005

[4] Naude B, Mudzi W, Mamabolo MV, et al. Low back pain among hospital employees in Gauteng, South Africa: Point prevalence and associated factors. Occup Health Southern Afr. 2009; 15(3): 24-30.

[5] Vieira ER, Kumar S, Coury HJCG, et al. Low back problems and possible improvements in nursing jobs. J. Adv. Nurs. 2006; 55(1): 79-89. PMid:16768742 http://dx.doi.org/10.1111/j $.1365-2648.2006 .03877 . x$

[6] Yip VY. New low back pain in nurses: work activities, work stress and sedentary lifestyle. J. Adv. Nurs. 2004; 46(4): 430440. PMid:15117354 http://dx.doi.org/10.1111/j.1365-2 $648.2004 .03009 . x$

[7] Serranheira F, Cotrim T, Rodrigues V, et al. Nurses from a working tasks and MSDs back symptoms: results national survey. Work. 2012; 41(Suppl 1): 2449-51. PMid:22317085

[8] Costa BR, Vieira ER. Risk factors for work-related musculoskeletal disorders: a systematic review of recent longitudinal studies. Amer J Ind Med. 2010; 53(3): 285-323. PMid:19753591

[9] Smith D, Leggat P. Musculoskeletal disorders among rural Australian nursing students. Aust. J. Rural Health. 2004; 12(6): 241245. PMid:15615575 http://dx.doi.org/10.1111/j.1440-1 $854.2004 .00620 . x$

[10] Verbeek J. When work is related to disease, what establishes evidence for a causal relation? Saf Health Work. 2012; 3(2): 11016. PMid:22993715 http://dx.doi.org/10.5491/SHAW. 2012 .3.2.110

[11] Hodder JN, Holmes MW, Keir PJ. Continuous assessment of work activities and posture in long-term care nurses. Ergonomics. 2010; 53(9): 1097-107. PMid:20737335 http://dx. doi .org/10.1080 /00140139.2010.502252

[12] Violante FS, Fiori M, Fiorentini C, et al. Associations of psychosocial and individual factors with three different categories of back disorder. J Occup Health. 2004; 46: 100-108. http://dx. doi . org/10.15 $39 /$ joh. 46.100

[13] Van Dienn J, Kuijer P, Burdorf A, et al. Non-specific low back pain. Lancet. 2012; 379(19): 1874. http://dx.doi .org/10.1016/S01 40-6736 (12) 60803-4

[14] Kwon BK, Roffey DM, Bishop PB, et al. Systematic review: occupational physical activity and low back pain. Occup Med. 2011; 61(8): 541-8. PMid:21727180 http://dx.doi.org/10.1093/occmed/ kqr092

[15] Alorusso A, Stefano B, Nicola L. A Review of Low Back Pain and Musculoskeletal Disorders among Italian Nursing Personnel. Industrial Health. 2007; 45(5): 637-644. http://dx.doi .org/10.2486 /indhealth. 45.637

[16] Boden LI, Sembajwe G, Tveito TH, et al. Occupational injuries among nurses and aides in a hospital setting. Am J Ind Med. 2012; 55(2): 117-26. PMid:22025077 http://dx.doi.org/10.1002/a jim. 21018 
[17] Kuijer PFM, Takala EP, Burdorf A, et al. Low back pain: doesn't work matter at all? Occup Med. 2012; 62(2): 153-4. http://dx.d oi.org/10.1093/occmed/kqr210

[18] Kuijer PFM, Frings-Dresen MHW, Gouttebarge V, et al. Low back pain: we cannot afford ignoring work. Spine J. 2011; 11: 164-8. PMid:21296301 http://dx.doi.org/10.1016/j.spine e.2010.10.016

[19] Lin PH, Tsai YA, Chen WC, et al. Prevalence, characteristics, and work-related risk factors of low back pain among hospital nurses in Taiwan: a cross-sectional survey. Int J Occ Envir Hyg. 2012; 25(1): 41-50. http://dx.doi.org/10.2478/s13382-012-0008-8

[20] Warnakulasuriya SS, Peiris-John RJ, Coggon D, et al. Musculoskeletal pain in four occupational populations in Sri Lanka. Occup Med. 2012; 62(4): 269-72. PMid:22661663 http://dx.doi.org/10. 1093/occmed/kqs057

[21] Woby RS, Watson JP, Roach KN, et al. Coping strategy use: does it predict adjustment to chronic back pain after controlling for catastrophic thinking and self -efficacy pain. J Rehabil Med. 2005; 37: 100-107. PMid:15788345 http://dx.doi.org/10.1080/16501 970410021535

[22] Turner JA, Clancy S. Strategies for coping with chronic low back pain: relationship to pain and disability. Pain. 1986 Mar; 24(3): 355-46. http://dx.doi .org/10.1016/0304-3959(86)90121-1

[23] Bourbonnais F. Pain assessment: Development of a tool for the nurse and the patient. J. Adv. Nurs. 1981; 6(4): 277-82. http: //dx.doi.org/10.1111/j.1365-2648.1981.tb03223.x

[24] Chen M. The Validation of the structure of the perceived meanings of pain Inventory. J. Adv. Nurs. 1999; 30(2): 344-351. PMid:10457236 http://dx.doi.org/10.1046/j.1365-2648.1999.01078.x

[25] Boyd M. Psychiatric nursing: contemporary practice(2nded.). Philadelphia: lipencott, Company. 2003; 260-574.

[26] Taylor C, Lillis C, Lemone P. Fundamental of nursing.Human health and function St Louis:Mosby year book. 1997; 124-250. PMid:9108817

[27] Folkman S, Lazarus R. Manual for The ways of coping questionnaire(Reserch Edition). Palo Alto, CA: Consultation psychologists. 1988.

[28] Spielberger C, Gorsuch R, lushene R. STIA Manual for State-Trait. Inc. California. 1970.

[29] Timby B, Smith N. Introductory medical surgical nursing (8th ed.) Philadelphia: lipencott, Williams \& Wilkins Company; 2003; 129 136.

[30] Al Hosis KF, Mersal FA, Keshk LI. Effects of Job Stress on Health of Saudi Nurses Working in Ministry of Health Hospitals in Qassim Region in KSA. Life Sci J. 2013; 10(1): 1036-1044.

[31] Schoenfisch AL, Lipscomb HJ, Pompeii LA, et al. Musculoskeletal injuries among hospital patient care staff before and after implementation of patient lift and transfer equipment. Scan J Work Env Health. 2013; 39(1): 27-36. PMid:22396049 http://dx.doi.org/10.52 $71 /$ sjweh. 3288
[32] Heutink M, Post WM, Overdulve C, et al. Which Pain Coping Strategies and Cognitions Are Associated with Outcomes of a Cognitive Behavioral Intervention for Neuropathic Pain after Spinal Cord Injury? Top Spinal Cord InjRehabil. 2013 Fall; 19(4): 330-340. PMid:24244098 http://dx.doi .org/10.1310/sci1904-330

[33] National Institute of Arthritis and Musculoskeletal and Skin Diseases. Handout on health: back pain. 2012. Available from: http://www . niams.nih.gov/Health_Info/Back_Pain/default.asp

[34] Balague F, Mannion AF, Pellise F, et al. Non-specific low back pain. Lancet. 2012; 379(9814): 482-91. http://dx. doi .org/10.1016 /S0140-6736 (11) 60610-7

[35] Schlossmacher R, Amaral F. Low back injuries related to nursing professionals working conditions: a systematic review. Work. 2012; 41(Suppl 1): 5737-8. PMid:22317669

[36] Karahan A, Kav S, Abbasoglu A, et al. Low back pain: prevalence and associated risk factors among hospital staff. Journal of Advanced Nursing. 2009; 65(3): 516-524. PMid:19222649 http: //dx.doi.org/10.1111/j.1365-2648.2008.04905.x

[37] Omokhodion FO, Umar US, Ogunnowo BE. Prevalence of low back pain among staff in a rural hospital in Nigeria. Occupational Medicine. 2000; 50(2): 107-110. http://dx.doi.org/10.1093/occmed/ 50.2 .107

[38] Nicholson PK, Nicholas MK, Middleton J, et al. Psychological characteristics of people with spinal cord injury-related persisting pain referred to a tertiary pain management center. J Rehabil Res Dev. 2009; 46(1): 57-67. http://dx.doi.org/10.1682/JRRD. 2008 .04 .0050

[39] Wong TS, Teo N, Kyaw MO. Prevalence and Risk Factors Associated with Low Back Pain Among Health Care Providers in a District Hospital. Malaysian Orthopaedic Journal. 2010; 14(2): 23-28.

[40] Feng Ck, Chen ML, Mao FI. Prevalence of and risk factors for different measures of low back pain among female nursing aides in Taiwanese nursing homes. BMC Musculoskeletal Disorders. 2007; 8(52): 1-9. http://dx.doi.org/10.1186/1471-2474-8-52

[41] Büssing A, Ostermann T, Matthiessen PF. Adaptive coping and spirituality as a resource in cancer patients. Breast Care. 2007; 2: 195-202. http://dx.doi.org/10.1159/000104172

[42] Büssing A, Ostermann T, Matthiessen PF. Wer kontrolliert die Gesundheit? - Adaptive Krankheitsverarbeitungsstile bei Patienten mit chronischen Erkrankungen. Deutsche Zeitschrift für Onkologie. 2008; 40(4): 150-156. http://dx.doi .org/10.1055/s-0028-1 082647

[43] Ramirez-Maestre C, Esteve R, Lopez AE. Cognitive appraisal and coping in chronic pain patients. Eur J Pain. 2008; 12: 749756. PMid:18096418 http://dx.doi.org/10.1016/j.ejpain. 2007.11.004

[44] Brown GK, Nicassio PM. Development of a questionnaire for the assessment of active and passive coping strategies in chronic pain patients. Pain. 1987; 31: 53-64. http://dx. doi.org/10.1016/0 304-3959 (87) 90006-6 